Jurnal Bisnis dan Manajemen, Volume 22, No. 2, September 2021, p. 162-175

\title{
MILLENNIAL CUSTOMER LOYALTY IN ONLINE SHOPPING ON DIGITAL PLATFORMS: A PERSPECTIVE OF NET PROMOTER SCORE
}

\author{
Slamet $^{1}$, Findi Dia Finalia Sari ${ }^{2}$, Indrayati ${ }^{3}$, Ilya Azmala ${ }^{4}$ \\ ${ }^{1,2}$ Universitas Islam Negeri Maulana Malik Ibrahim Malang, Indonesia \\ ${ }^{3}$ Politeknik Negeri Malang, Indonesia \\ ${ }^{4}$ Universitas Brawijaya, Indonesia
}

\begin{abstract}
This study maps and analyses the customer loyalty level, namely, the Millennials aged 23-38 shopping online through digital platforms in 2020. The study's objects include, Bukalapak.com, Shopee.co.id, Tokopedia.com, Bibbli.com, Lazada.co.id, Carrefour.co.id, Indomaret.com, Zalora.co.id, Tiket.com, Traveloka.com, Gojek.com, Grab.com, and Gopay.com. The survey was conducted in Malang City and Regency, Indonesia. The instrument used was a questionnaire containing the respondent's profile and a single question about the willingness to offer recommendations to friends or colleagues. The questionnaire was circulated using Google Forms through WhatsApp and email. Furthermore, descriptive statistical analysis was used to describe the data in percentage, while the Net Promoter Score (NPS) method was used to determine customer category. The results showed that most consumers using the digital platform were in the Detractor (46.15\%), including Lazada.co.id (NPS=$1.30 \%$ ), Tiket.com (NPS-1.80\%), Carrefour.co.id (NPS=-3.66\%), Zalora.co.id (NPS=-3.68\%), Bukalapak.com (NPS=12.03), and Blibli.com (NPS=-18.13\%). It means those platforms have disloyal consumers due to poor service. The second level is in the Passive category (38.46\%), including Gojek.com (NPS=39.48\%), Traveloka.com (NPS=32.92\%), Tokopedia.com (NPS=23.82\%), Gopay.com (NPS=23.4\%), and Indomaret.com (NPS=22.91\%). It means their services are satisfactory. Only $15.38 \%$ of consumers are in the Promoter, namely Shopee.co.id (NPS=53.86\%) and Grab.com $(\mathrm{NPS}=56.32 \%)$. The services of these platforms are excellent, and their customers are very loyal. Thus, based on the NPS method, digital platform users in Indonesia are mostly Detractor and Passive users, very few in the Promoter category.
\end{abstract}

Keywords: Net Promoter Score, Customer loyalty, Millennials, online shopping, Platform Digital

\section{LOYALITAS PELANGGAN MILENIAL DALAM BELANJA ONLINE DI PLATFORM DIGITAL: PERSPEKTIF NET PROMOTER SCORE}

\begin{abstract}
ABSTRAK
Studi ini memetakan dan menganalisis tingkat loyalitas pelanggan Milenial berusia 23-38 tahun yang berbelanja daring melalui platform digital pada tahun 2020. Objek studi ini meliputi Bukalapak.com, Shopee.co.id, Tokopedia.com, Bibbli.com, Lazada.co.id, Carrefour.co.id, Indomaret.com, Zalora.co.id, Tiket.com, Traveloka.com, Gojek.com, Grab.com, dan Gopay.com. Survei dilakukan di Kota dan Kabupaten Malang, Indonesia. Instrumen penelitian berupa kuesioner yang berisi profil responden dan satu pertanyaan tentang kesediaan memberikan rekomendasi kepada teman atau kolega. Kuesioner didistribusikan menggunakan Google Forms melalui WhatsApp dan email. Selanjutnya, analisis deskriptif statistik digunakan untuk menggambarkan data dalam bentuk prosentase, sedangkan metode Net Promoter Score (NPS) digunakan untuk menentukan kategori pelanggan. Hasil studi menunjukkan bahwa kebanyakan pengguna platform digital berada dalam kategori Detractor (46,15\%), meliputi Lazada.co.id (NPS=-1,30\%), Tiket.com (NPS=-1,80\%), Carrefour.co.id (NPS =3,66\%), Zalora.co.id (NPS=-3,68\%), Bukalapak.com (NPS=-12,03), dan Blibli.com (NPS=-18,13\%). Artinya, platform digital tersebut memiliki konsumen yang tidak loyal karena layanan yang buruk. Tingkat kedua berada dalam kategori Pasif (38,46\%), diantaranya Gojek.com (NPS=39,48\%), Traveloka.com (NPS=32,92\%), Tokopedia.com (NPS=23,82\%), Gopay.com (NPS=23,4\%), dan Indomaret.com (NPS=22,91\%). Artinya, layanan dianggap baik dan memuaskan. Hanya 15,38\% konsumen berada dalam kategori pelanggan Promoter, yaitu Shopee.co.id (NPS=53,86\%) dan Grab.com $(N P S=56,32 \%)$. Layanan dua platform ini sangat baik dan konsumennya sangat loyal. Maka, berdasarkan metode NPS, pengguna platform digital di Indonesia sebagian besar adalah pelanggan Detractor dan Pasif, sangat sedikit dalam ketegori pelanggan Promoter.
\end{abstract}

Kata-kata kunci: Net Promoter Score, Loyalitas Pelanggan, Milenial, Belanja Online, Platform Digital.

Korespondensi: Slamet, S.E., M.M., Ph.D, Universitas Islam Negeri Maulana Malik Ibrahim Malang, Jln. Gajayana 50 Malang (65144). Email: slametphd@manajemen.uin-malang.ac.id.

Submitted: June 2021, Accepted: September 2021, Published: September 2021

ISSN: 1412 - 3681 (printed), ISSN: 2442 - 4617 (online), Website: http://journal.feb.unpad.ac.id/index.php/jbm 


\section{INTRODUCTION}

The digital economy plays a direct role in changing the traditional market structure (Demenko \& Savina, 2019). This is due to the role and development of internet technology (F. Wang \& Zhang, 2015), which drive transformation. The term digital transformation refers to the processes and strategies of using technology to change business operations and services (SAS, 2020). Meanwhile, Indonesia is among the ten largest countries with digital trade or e-commerce growth (78\%) (SkalaNews, 2019). Furthermore, it has five largest digital platforms in terms of customers' population, which include Shopee.co.id (93.4 million), Tokopedia.com (84.1 million), Bukalapak.com (35.2 million), Lazada.co.id (22 million), and Blibli.com (18.3 million) (Iprice, 2020a; Sirclo, 2020; Statista Research Department, 2020). This is followed by an on-demand based digital platforms, such as Gojek.com and Grab.com. Also, Iprice Group showed the use of shopping applications increased by 39\%, and Indonesia was ranked the highest (Iprice, 2020b). Hence, with the ever-evolving digital-based business, there has been increased competition (Pratminingsih et al., 2013). This condition also changes consumer's behavior in shopping (Eroglu, 2014). Therefore, it can be predicted that digitalbased consumers will continue to increase.

This increase is evidenced by the global trend, and over $50 \%$ of consumers have used mobile devices in accessing digital platforms to compare prices before purchasing. In Asia, approximately $60 \%$ of consumers diligently compare prices through gadgets before making a purchase (Rossanty et al., 2018). The effect of this condition is how to retain customers, which are company's assets (Rahman, 2016), and can create profitability. One strategy to realize this problem is by building customer satisfaction and loyalty. In fact, several parties believe that e-loyalty is significantly influenced by e-satisfaction (Biscaia et al., 2017; Chen, 2012; Pratminingsih et al., 2013; Rafiq et al., 2013; Wu \& Tseng, 2014).

Simultaneously, satisfaction, trust, and commitment have a significant influence on loyalty in online shopping (Pratminingsih et al., 2013). Also, the website design has an influence on trust, which influences loyalty (Siagian \& Cahyono, 2014). Rafiq, Fulford, and Lu (2013) stated that technology acceptance level or website quality has an influence on e-satisfaction, and e-loyalty is influenced by communication, relationship investment, as well as commitment. Furthermore, Bilgihan (2016) stated that trust is a key factor to realize e-loyalty in online shopping among Millennials. Therefore, in online-based business, people need to identify customer satisfaction and loyalty.

Net Promoter Score (NPS) is a method used in tracking customer loyalty, enthusiasm, and engagement (Reichheld, 2011). Furthermore, it is widely used to measure the level of customer loyalty from various contexts, including the loyalty of banking customer (Simarmata, 2019), public services (Asmara \& Ratnasari, 2016), product 
Jurnal Bisnis dan Manajemen, Volume 22, No. 2, September 2021, p. 162-175

brands (Situmorang et al., 2017), university services (Chaffin, 2018; Lee, 2018), hospital services (Hamilton et al., 2014; Krol et al., 2015), mobile phone business (Wohllebe et al., 2020), business services (Mecredy et al., 2018), and eWOM behavior (Raassens \& Haans, 2017). Based on the NPS index, Eger \& Mičík (2017) proved that satisfaction (of the overall satisfaction items) has a positive correlation with customer loyalty. Therefore, the NPS method is widely used to identify and measure the level of customer loyalty from various contexts.

This study aims to measure and map the loyalty of Millennial digital platform users by employing the NPS method. Here, loyalty is characterized by customers willingness to recommend friends and colleagues to participate in positive experiences of online shopping. This study was based on the argument that low switching costs in a digital business model means consumers can simultaneously and quickly move from one platform to another. In this model, consumers emotionally do not feel that they are getting adequate attention and service from business providers. Moreover, the nature of the human ego as a consumer always wants to be appreciated and respected. In a digital platform-based business model, consumers tend to be disloyal and their loyalty is difficult to build. Therefore, the NPS method can be used to indicate and measure the level of loyalty in performing online shopping. This argument is included as a hypothesis in this study.

\section{LITERATURE REVIEW}

\section{Customer loyalty}

In previous studies, two terms were found, namely consumer and customer loyalty. Some studies use the term consumer loyalty (Delgado-Ballester \& Luis Munuera-Alemán, 2001; Hermawan, 2015; Lewis \& Soureli, 2006; Oliver, 1999; So et al., 2016; Srivastava \& Kaul, 2016; S. Wang et al., 2017; Yu \& Dean, 2001), while others use customer loyalty (Budianto, 2019; Chen, 2012, 2015; Kiseleva et al., 2016; Lafley et al., 2017; Leninkumar, 2017; Setiawan \& Sayuti, 2017). According to Oxford Learner's Dictionary, a consumer is someone who buys goods/services. Furthermore, a customer is a person or organization that purchases goods/services from a store or business (Oxford University Press, 2019). Consumers are different from customers because the former are end users and do not repeat purchases. However, customers are consumers (individuals/organizations) who have made purchases more than once (Wahyono, n.d.). Therefore, this study used the term customer loyalty, and asserts that Millennials are individuals who can repeat purchases on the same digital platform.

Customer loyalty concept is a method of predicting attitudes and behavior (East et al., 2005; Setiawan \& Sayuti, 2017), such as willingness to recommend others, reducing searches, having the intention of buying the same product/company brand repeatedly, having a positive view of product/service, commitment to the company, and refusal to switch to competitors (East et al., 2005; 
Jurnal Bisnis dan Manajemen, Volume 22, No. 2, September 2021, p. 162-175

Mowen \& Minor, 2001; Oliver, 1999; Zeithaml et al., 1996). Also, the objects of loyalty are brands, shops, services or companies (East et al., 2005). Therefore, loyalty is seen as a strong relationship between individual attitudes and patronage (Dick \& Basu, 1994). The relationship framework of customer loyalty is shown in Figure 1. The logical consequence of customer loyalty is the purchase of more products/services, even though the brand is different, but from the same company, and importantly, the willingness to provide recommendation to friends and colleagues. In this study, the NPS method was used to identify and measure loyalty level.

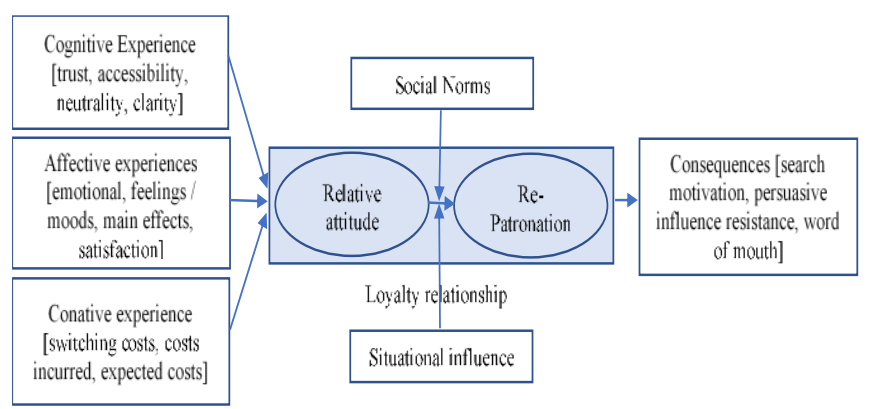

Figure 1. Consumer Loyalty Framework Source: (Dick \& Basu, 1994)

\section{Net Promoter Score}

The NPS method developed by (Reichheld, 2011) is used to track customer loyalty, enthusiasm, and engagement. In fact, it is both a score and a system (Bendle et al., 2019). As a score, it is the simplest method to measure loyalty and estimate income growth (Mecredy et al., 2018). Furthermore, it is a single-point metric designed to calculate whether a user highly appreciates a service or not. In fact, relies specifically on one question, which is, "Based on your experience, would you like to recommend this service to your family, colleagues or friends?" The answer to the question is in score form with a scale of 0-10 (Chaffin, 2018). The score is divided into three categories, namely Detractor (score 0 - 6), Passive (score 7-8), and Promoter (score 9-10) (Chaffin, 2018; Reichheld, 2011).

According to Reichheld (2011), the Detractor category is a group of people who are dissatisfied and disappointed with the way consumers are treated. This group likes to speak ill of the company to friends and colleagues. In fact, they are likely to be annoying and complain about the company when they cannot switch to another provider. Meanwhile, a Passive category is a group of people who are passively satisfied, but not loyal. They have little or no enthusiasm to recommend others, and tend to easily switch to competing companies when there are discounts from competitors. This group is known as passive because they generate very little energy for the company and cannot be used as a long-term asset. Lastly, the Promoter category is a group of loyal customers and usually make repeated purchases. This group likes talking about the positive experiences of the company to friends and colleagues. Furthermore, they voluntarily take the time to respond to surveys and offer feedback as well as constructive suggestions.

NPS as a system is a follow-up from the changing score to further investigation of the customer experience. Moreover, it does not only monitor metrics, but also changes the company's culture into that which puts customers first (Bendle et al., 2019). Therefore, NPS is used as income 
Jurnal Bisnis dan Manajemen, Volume 22, No. 2, September 2021, p. 162-175

justification based on the identification of loyal customers who recommend potential clients, and income is obtained (Mecredy et al., 2018). The company as a system automatically engages senior management about the importance of customer recommendations, action to improve experience and monitor progress (Bendle et al., 2019). Therefore, NPS as a score is the initial justification for improving service management. Based on quality service management, it is expected to foster customer satisfaction or loyalty, and automatically increase company revenue. Also, as a universal method, it is used to identify and measure customer loyalty from various objects, one of which is digital platform users.

\section{Digital Platform}

According to IGI Global, there are many definitions of digital platforms: (1) a system and interface in a network or commercial market to facilitate business to business (B2B), business to consumer (B2C), or consumer to consumer (C2C) transactions, (2) electronic devices with communication function, such as desktop software, mobile, social media, e-mail, covering websites and social media, (3) the website software or hardware that allows interaction between users, (4) a facility which provides space for users to collaborate, interact, transact digitally, (5) a twosided marketplace involving suppliers and consumers in digital transactions and exchanges (IGI Global, n.d.).

The core concept of digital platforms according is presented in Table 1.
Table 1. Definition of the Digital Platform

\begin{tabular}{|c|c|}
\hline Concept & \\
\hline Multi-sided platform & $\begin{array}{l}\text { Able to mediate from } \\
\text { different groups. }\end{array}$ \\
\hline Multi-sided markets & $\begin{array}{l}\text { Able to unite different } \\
\text { segments and increase the } \\
\text { number of consumers from } \\
\text { various sides. }\end{array}$ \\
\hline $\begin{array}{l}\text { Direct network } \\
\text { externalities }\end{array}$ & $\begin{array}{l}\text { Directly have a value network } \\
\text { with the same external parties } \\
\text { or groups. }\end{array}$ \\
\hline $\begin{array}{l}\text { Indirect network } \\
\text { externalities }\end{array}$ & $\begin{array}{l}\text { Indirectly has a value network } \\
\text { with different external parties } \\
\text { or groups. }\end{array}$ \\
\hline $\begin{array}{l}\text { Digital platform } \\
\text { (technical view) }\end{array}$ & $\begin{array}{l}\text { From a technical point of } \\
\text { view, it is possible to unify } \\
\text { various modules with a } \\
\text { codebase supplemented by } \\
\text { third parties. }\end{array}$ \\
\hline $\begin{array}{l}\text { Digital platform } \\
\text { (socio-technical } \\
\text { view) }\end{array}$ & $\begin{array}{l}\text { From a socio-technical } \\
\text { perspective, able to link } \\
\text { technical elements with } \\
\text { processes and standards } \\
\text { within an organization. }\end{array}$ \\
\hline $\begin{array}{l}\text { Eco } \\
\text { (tecl }\end{array}$ & $\begin{array}{l}\text { From a technical point of } \\
\text { view, a collection of } \\
\text { applications that complement } \\
\text { each other on the main } \\
\text { platforms are mostly provided } \\
\text { by third parties. }\end{array}$ \\
\hline $\begin{array}{l}\text { Ecosystem } \\
\text { (organizational } \\
\text { view) }\end{array}$ & $\begin{array}{l}\text { From an organizational } \\
\text { perspective, interactions } \\
\text { between organizations are } \\
\text { complementary. }\end{array}$ \\
\hline Applications & $\begin{array}{l}\text { Software that combines } \\
\text { certain features in the form of } \\
\text { systems and services that } \\
\text { users can access. }\end{array}$ \\
\hline Bound & $\begin{array}{l}\text { Software that facilitates the } \\
\text { relationship between the } \\
\text { company and the parties } \\
\text { involved in the long term. }\end{array}$ \\
\hline Platf & $\begin{array}{l}\text { Have limited resources but } \\
\text { complement each other. }\end{array}$ \\
\hline
\end{tabular}

Source: (Malinverno \& Moyer, 2017).

\section{METHODS}

This study utilized a quantitative paradigm with a survey approach. Meanwhile, the digital platform users include Bukalapak.com, Shopee.co.id, 
Jurnal Bisnis dan Manajemen, Volume 22, No. 2, September 2021, p. 162-175

Tokopedia.com, Bibbli.com, Lazada.co.id, Carrefour.co.id, Indomaret.com, Zalora.co.id, Tiket.com, Traveloka.com, Gojek.com, Grab.com, and Gopay.com. Furthermore, the population was the Millennials generation in Malang City and Regency, East Java, Indonesia. According to the Pew Research Center, Millennials are people between 23 - 38 years or born in 1981-1996 (Dimock, 2019). Others stated that they are born in the 1980s - mid 1990s to early 2000s (Wikipedia, 2020). These individuals were selected as subjects because they are active internet users (KumparanTech, 2018; Novianty, 2019), and they behave differently from previous generations. Millennials grew up together with the development of information technology, the internet and the emergence of a middle-class economy in Indonesia since the 21st century (Rossanty et al., 2018).

The sample was Millennials who use digital marketplace or online shops. 500 respondents were selected because the population size was not identified with certainty, and is heterogeneous in nature. Furthermore, a purposive sampling technique was used, and the study instrument was a questionnaire. This was used to identify the respondents' profile about having or never using a digital platform in the past year. There was also a single question about their experience using a digital platform and willingness to provide recommendations to friends or colleagues. The questionnaire was designed as a google form and distributed through various Millennial Whatsapp Groups. Subsequently, data were obtained from primary sources through survey techniques.
Data analysis was carried out using the NPS method, and the score criteria ranged from -100 to +100 , which means worst and best respectively. Furthermore, a score of $0<\mathrm{NPS} \leq 50$ means the service is considered good, while $50<$ NPS $\leq 70$ means the service is very good. Moreover, an NPS of $>70$ means the best in its class, while negative score is generally associated with poor service and disloyal customers (Lee, 2018). The score was obtained by the formula: Promoter (\%) - Detractor (\%) (Chaffin, 2018; Reichheld, 2011).

\section{RESULTS AND DISCUSSION}

\section{Results}

This study involved millennial groups with a total of 500 respondents. This study involved millennial groups with a total of 500 respondents, in which $248(49.60 \%)$ were males and $252(50.40 \%)$ were females. A total of 451 respondents were between 20 to 29 years $(90.20 \%)$, while the other 49 were between 30 to 40 years $(9.80 \%)$. Also, as many as $224(44.80 \%)$ respondent domicile in the regency and $276(55.20 \%)$ in the city areas. Briefly presented in Figure 2.

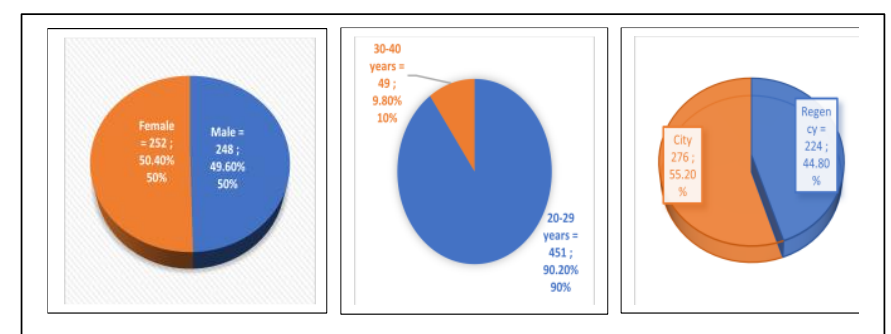

Figure 2. Respondent Characteristic

Source: Primary Data (processed, 2020)

Figure 3 below presents survey data on digital platforms that are widely accessed by Millennials. 
Jurnal Bisnis dan Manajemen, Volume 22, No. 2, September 2021, p. 162-175

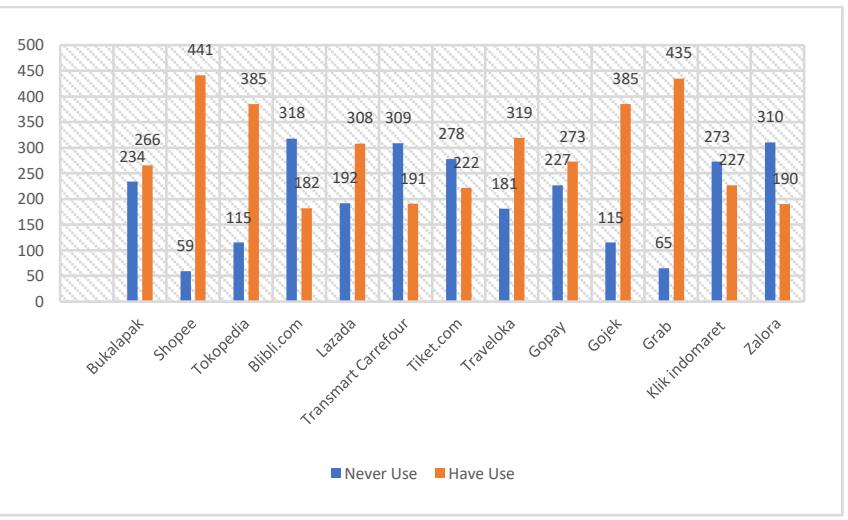

Figure 3. Distribution of Digital Platform Access by Millennials

Source: Primary Data (processed, 2020).

Figure 3 shows the digital platforms frequently accessed by Millennials are Grab.com, Gojek.com, Tokopedia.com, and Shopee.co.id. Based on the presented data, respondents were asked about their experience and follow-up actions in performing online shopping.

Subsequently, they gave scores: 9 - 10 (promoter), 7 - 8 (passive), or 0 - 6 (detractors) on each digital platform they have visited for shopping. The survey identification results are presented in Table 2 and Table 3.

Table 2. Distribution of respondents' experience after shopping on a digital platform

\begin{tabular}{|c|c|c|c|c|c|c|c|c|c|c|c|c|c|}
\hline \multirow{2}{*}{ No } & \multirow{2}{*}{ Platform Name } & \multicolumn{7}{|c|}{ Detractor } & \multicolumn{2}{|c|}{ Passive } & \multicolumn{2}{|c|}{ Promoter } & \multirow{2}{*}{ - Total } \\
\hline & & 0 & 1 & 2 & 3 & 4 & 5 & 6 & 7 & 8 & 9 & 10 & \\
\hline 1 & Shopee & 0 & 0 & 0 & 0 & 1 & 17 & 22 & 50 & 72 & 213 & 66 & 441 \\
\hline 2 & Grab & 0 & 0 & 0 & 1 & 4 & 14 & 5 & 70 & 73 & 203 & 65 & 435 \\
\hline 3 & Tokopedia & 0 & 0 & 0 & 0 & 3 & 35 & 29 & 63 & 100 & 148 & 7 & 385 \\
\hline 4 & Gojek & 0 & 0 & 0 & 0 & 5 & 20 & 14 & 79 & 74 & 123 & 70 & 385 \\
\hline 5 & Traveloka & 0 & 0 & 0 & 0 & 3 & 35 & 18 & 52 & 52 & 124 & 35 & 319 \\
\hline 6 & Lazada & 0 & 0 & 0 & 0 & 3 & 49 & 34 & 59 & 81 & 72 & 10 & 308 \\
\hline 7 & Gopay & 0 & 0 & 0 & 1 & 5 & 31 & 16 & 56 & 47 & 107 & 10 & 273 \\
\hline 8 & Bukalapak & 0 & 0 & 0 & 0 & 11 & 64 & 22 & 50 & 55 & 48 & 16 & 266 \\
\hline 9 & Klik Indomaret & 0 & 0 & 0 & 0 & 2 & 27 & 16 & 27 & 59 & 84 & 12 & 227 \\
\hline 10 & Tiket.Com & 0 & 0 & 0 & 2 & 3 & 34 & 22 & 42 & 63 & 48 & 8 & 222 \\
\hline 11 & Transmart Carrefour & 0 & 0 & 0 & 0 & 2 & 45 & 16 & 37 & 34 & 48 & 9 & 191 \\
\hline 12 & Zalora & 0 & 0 & 0 & 0 & 1 & 38 & 16 & 40 & 47 & 40 & 8 & 190 \\
\hline 13 & Bibli.com & 0 & 0 & 0 & 0 & 0 & 48 & 21 & 31 & 48 & 34 & 0 & 182 \\
\hline
\end{tabular}

Source: Primary Data (processed, 2020).
Table 3. Total of Respondents' experience after shopping on a digital platform

\begin{tabular}{|c|c|c|c|c|c|}
\hline \multirow{2}{*}{ No } & \multirow{2}{*}{ Platform Name } & Detractor & Passive & Promoter & \multirow{2}{*}{ Total } \\
\hline & & $(0-6)$ & $(7-8)$ & $(9-10)$ & \\
\hline 1 & Shopee & 40 & 122 & 279 & 441 \\
\hline 2 & Grab & 24 & 143 & 268 & 435 \\
\hline 3 & Tokopedia & 67 & 163 & 155 & 385 \\
\hline 4 & Gojek & 39 & 153 & 193 & 385 \\
\hline 5 & Traveloka & 56 & 104 & 159 & 319 \\
\hline 6 & Lazada & 86 & 140 & 82 & 308 \\
\hline 7 & Gopay & 53 & 103 & 117 & 273 \\
\hline 8 & Bukalapak & 97 & 105 & 64 & 266 \\
\hline 9 & Klik Indomaret & 45 & 86 & 96 & 227 \\
\hline 10 & Tiket.Com & 61 & 105 & 56 & 222 \\
\hline 11 & Transmart Carrefour & 63 & 71 & 57 & 191 \\
\hline 12 & Zalora & 55 & 87 & 48 & 190 \\
\hline 13 & Bibli.com & 69 & 79 & 34 & 182 \\
\hline & Mean Score & 58.08 & 112.38 & 123.69 & \\
\hline
\end{tabular}

Source: Primary Data (processed, 2020).

Based on the data presented in Table 3, the score is above the mean by categories:

1. Detractor category includes: Tokopedia.com, Lazada.co.id, Bukalapak.com, Tiket.com, Transmart Carrefour.co.id, and Blibli.com.

2. Passive category includes: Shopee.co.id, Grab.com, Tokopedia.com, Gojek.com, and Lazada.co.id.

3. Promoter category includes: Shopee.co.id, Grab.com, Tokopedia.com, Gojek.com, and Traveloka.com.

Graphically, the results are presented in Figure 4.

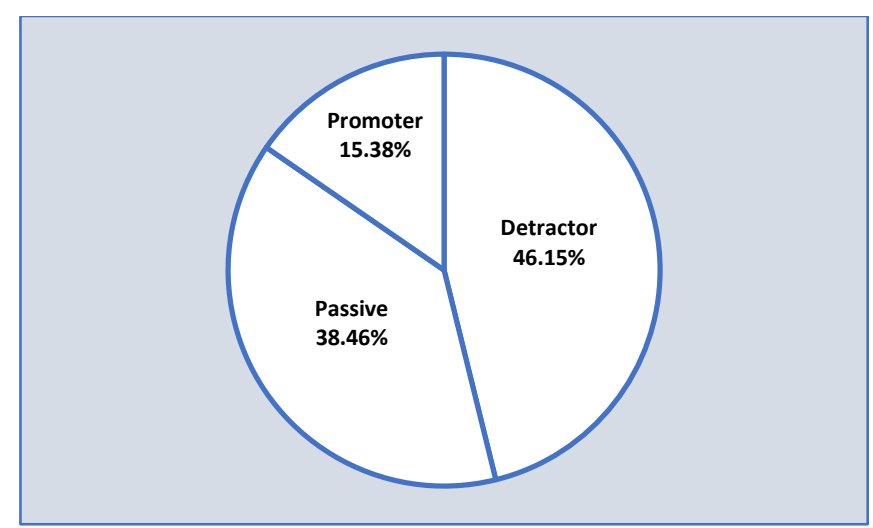

Figure 4. Respondent Status Group

Source: Primary Data (processed, 2020) 
Jurnal Bisnis dan Manajemen, Volume 22, No. 2, September 2021, p. 162-175

Based on Table 3, the calculation was carried out using the NPS formula and the results are shown in Table 4.

Table 4. The Calculation of Net Promoter

\begin{tabular}{llcccc}
\multicolumn{5}{c}{ Score } \\
\hline No & Platform Name & Detractor & Passive & Promoter & $\begin{array}{c}\text { NPS } \\
\text { (Absolute) }\end{array}$ \\
\hline 1 & Grab & $5.52 \%$ & $32.87 \%$ & $61.61 \%$ & 56.09 \\
2 & Shopee & $9.07 \%$ & $27.66 \%$ & $63.27 \%$ & 54.20 \\
3 & Gojek & $10.13 \%$ & $39.74 \%$ & $50.13 \%$ & 40.00 \\
4 & Traveloka & $17.55 \%$ & $32.60 \%$ & $49.84 \%$ & 32.29 \\
5 & Gopay & $19.41 \%$ & $37.73 \%$ & $42.86 \%$ & 23.44 \\
6 & Tokopedia & $17.40 \%$ & $42.34 \%$ & $40.26 \%$ & 22.86 \\
7 & Klik Indomaret & $19.82 \%$ & $37.89 \%$ & $42.29 \%$ & 22.47 \\
8 & Lazada & $27.92 \%$ & $45.45 \%$ & $26.62 \%$ & -1.30 \\
9 & Tiket.Com & $27.48 \%$ & $47.30 \%$ & $25.23 \%$ & -2.25 \\
10 & Transmart Carrefour & $32.98 \%$ & $37.17 \%$ & $29.84 \%$ & -3.14 \\
11 & Zalora & $28.95 \%$ & $45.79 \%$ & $25.26 \%$ & -3.68 \\
12 & Bukalapak & $36.47 \%$ & $39.47 \%$ & $24.06 \%$ & -12.41 \\
13 & Bibli.com & $37.91 \%$ & $43.41 \%$ & $18.68 \%$ & -19.23 \\
\hline
\end{tabular}

Source: Primary Data (processed, 2020).

According to Table 4, NPS score varies between -19.23 and 56.09 and graphically presented in Figure 5.

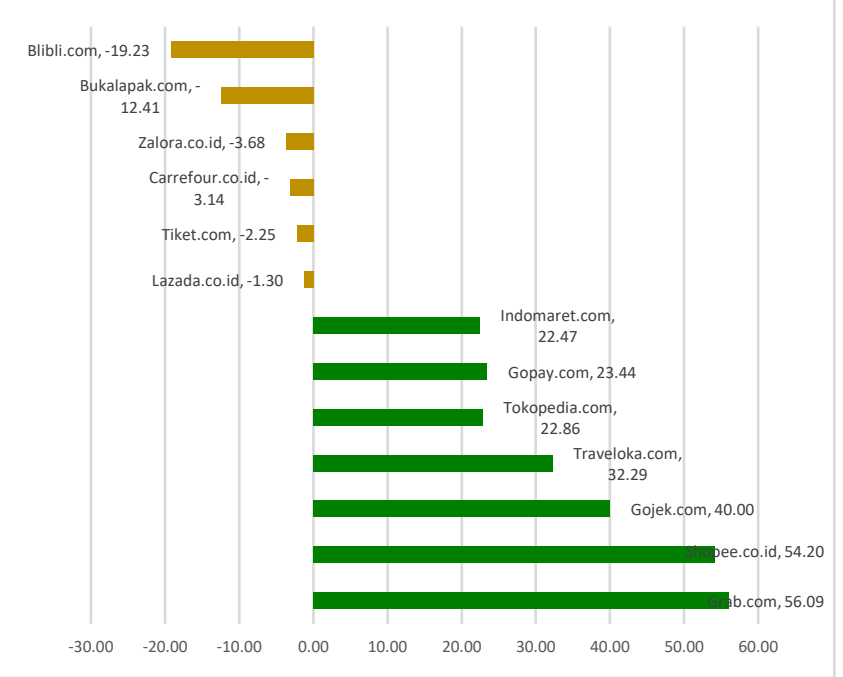

Figure 5. The Ranking of Net Promoter Score Source: Primary Data (processed, 2020)

\section{DISCUSSION}

Based on the NPS method, from the 13 digital platforms used in this study, $46 \%$ have Detractor, $39 \%$ have Passive, and only $15 \%$ have Promoter category customers. Furthermore, the digital platforms with loyal customers (Promoter category) were Grab.com and Shopee.co.id. This finding was reinforced by descriptive analysis results. The two digital platforms were often accessed by Millennials and provided positive experiences on its electronic services (see Figure 2 and 3). Meanwhile, the platforms with satisfied but disloyal customers (Passive category) include Gojek.com, Traveloka.com, Tokopedia.com, Gopay.com, and Indomaret.com. The disloyal customers are characterized by the reluctance of telling positive things about the company and unwilling to recommend to friends or colleagues about their experiences (Reichheld, 2011). Furthermore, the platforms with unsatisfied customers or negative experiences (Detractor category) include Bukalapak.com, Bibbli.com, Lazada.co.id, Carrefour.co.id, Zalora.co.id, and Tiket.com. Reichheld (2011) suggested that customers in this category should be wary, because they are dangerous and are likely to damage the good reputation of the company. Therefore, there are differences in the level of Millennials customer loyalty in performing online shopping.

The differences in customer categories above, which are dominated by Detractor customers, showed Millennials are very sensitive to technical and non-technical services developed by digital platform vendors. This generation grew up with the development of digital technology and social media. At the same time, they get various 
Jurnal Bisnis dan Manajemen, Volume 22, No. 2, September 2021, p. 162-175

forms of online shopping offers from different platforms with similarities in business models and processes. Meanwhile, the quality of online shopping services through digital platforms is largely determined by the business eco-system, which includes platform vendors, product/service owners, internet service providers, and expeditions. Besides, the lifestyle, nature, and behavior of the Millennials as well as the low switching-costs promote this generation to move from one platform to another. Due to this condition, customers tend to be disloyal to a particular platform. Therefore, based on the NPS method, there are different categories of customers, namely loyal (Promoter), satisfied (Passive), and depreciators (Detractor).

The differences in loyalty level is caused by two factors, namely the individual and the technical or non-technical factors of the vendor. Individual factors are shaped by the background, lifestyle, perspective, nature, and behavior of Millennials. Furthermore, they grew up with the tremendous digital technology development and social media. Millennials are also quicker to accept various forms of digital technology development and differentiate the available platforms. Currently, they dominate the internet (Novianty, 2019), mostly for online shopping (Cahya, 2020). Also, this generation has several characteristics when performing online shopping, such as browsing information or services first, never regretting online shopping despite having a bad experience, fussy, considering promotions, and access to trusted platforms (Wicaksono, 2019). Meanwhile, the technical and non-technical factors include website design quality, technology acceptance, access speed, data privacy security, breadth of access, communication, relationships, vendor commitment, trust, accuracy, and convenience. These factors have an impact on digital platform choice and e-loyalty (Bilgihan, 2016; Rafiq et al., 2013; Rossanty et al., 2018; SivaKumar \& Gunasekaran, 2017). Therefore, based on the NPS method, Millennials dominate online shopping with the Detractor category, which is different from previous studies.

Chaffin (2018) used NPS to measure students as library users at Washington University, and the result showed there is a difference in loyalty level between fall and spring. In the fall, the Promoter category was $41 \%$, Passive $29 \%$, and Detractor 30\%. Conversely, in the spring, the Promoter category was $18 \%$, Passive $36 \%$, and Detractor $46 \%$. Furthermore, Lee (2018) used NPS to measure satisfaction with AITS services at Illinois University, and the results showed the loyalty level was very high with a score of $77 \%$. Simarmata (2019) used NPS to measure bank customers, and the results showed the Promoter category was $69 \%$, Passive $16 \%$, and Detractor 15\%. Also, Asmara and Ratnasari (2016) used NPS to measure the loyalty of visitors to Tourist Area, and the results were dominated by Passive category visitors with $55 \%$, Detractors with $29 \%$, and promoters with $16 \%$. Hamilton et al. (2014) stated that the method is used to assess patient's treatment outcomes, whether they are willing to recommend their experiences to others. According to Krol, de Boer, Delnoij, and Rademakers (2015), NPS was 
Jurnal Bisnis dan Manajemen, Volume 22, No. 2, September 2021, p. 162-175

used to determine patient experience and satisfaction. In contrast to previous studies, Situmorang, Rini, and Muda (2017) used this method as the dependent variable in testing brand competition. The result showed NPS as the dependent variable was positively and significantly influenced by customer experience and net emotional value.

Based on this study, digital platform vendors should be attentive to two factors, namely individual and technical or non-technical factors. Also, Millennials as well as future generations are the ruling and active users of digital technology, the internet, and social media as online shopping channels (Cahya, 2020; Novianty, 2019). Moreover, technical and non-technical factors should also be interpreted. Several studies have warned and suggested the importance of these two factors, because many platforms do not pay attention to them. Also, Millennials need accuracy, speed, security, broad access, and comfort (Rossanty et al., 2018). SivaKumar and Gunasekaran, (2017) proved that there was a positive relationship between web design, layout, and user interface with the ease of finding and selecting products when performing online shopping. Furthermore, Pudjarti, Nurchayati, and Putranti (2019) stated that there was a positive and significant relationship between service quality, esatisfaction, and e-loyalty. Besides, non-technical factors are also more important. Rafiq, Fulford, and Lu (2013) stated that communication, relationship investment, and commitment have a strong influence on the formation of e-loyalty. This was confirmed by Bilgihan (2016) that trust is an important factor of realizing e-loyalty in online shopping. Therefore, the factors of efficiency, fulfillment, reliability, privacy, responsiveness, compensation, and contacts availability need to be considered (Widyanita, 2018).

\section{CONCLUSION}

The findings of this study indicate that consumer loyalty on digital platforms is mostly in the detractor category, the second group is the passive consumer category, and the third group is the promoter consumer category. This study proves that the consumer group in the promoter category is less than $20 \%$, and the consumer group in the detractor category is more than $40 \%$. This finding is caused by the character of the Millennial generation who prefers to shop on the move. The second is due to the low switching costs of online shopping, and the third is due to the absence of a direct relationship with the service provider. In addition, the vendor's lack of attention to technical and non-technical factors also contributed to the detractor category of consumers. Thus, consumer loyalty on digital platforms as measured by the NPS method is depicted in an inverted pyramid: Detractor, Passive, and Promoter.

The weakness of this research is that it only involves the NPS method. The NPS method measures the level of loyalty with a single question involving a scale of $0-10$. It turns out that customer loyalty cannot be identified with just a single question but must be identified from various measurement dimensions. The second weakness is 
Jurnal Bisnis dan Manajemen, Volume 22, No. 2, September 2021, p. 162-175

that it only involves one consumer characteristic:

the Millennial generation who shop online.

Therefore, it is recommended for further researchers to combine the NPS method with other methods in measuring consumer loyalty. The combination of these methods is intended to obtain a perfect measurement of consumer loyalty. Second, it is recommended to involve consumers who do shopping directly to meet the provider. Thus, it is hoped that it can provide unique information or research findings.

\section{REFERENCES}

Asmara, Y., \& Ratnasari, V. (2016). Analisis Kepuasan dan Loyalitas Pengunjung Terhadap Pelayanan di Kawasan Wisata Goa Selomangleng Kota Kediri dengan Pendekatan Structural Equation Modeling. Sains Dan Seni Its, 5(2), 181-186. https://media.neliti.com/media/publications/1322 14-ID-analisis-kepuasan-dan-loyalitaspengunju.pdf

Bendle, N. T., Bagga, C. K., \& Nastasoiu, A. (2019). Forging a Stronger Academic-Practitioner Partnership-The Case of Net Promoter Score (NPS). Journal of Marketing Theory and Practice, 27(2),

210-226. https://doi.org/10.1080/10696679.2019.1577689

Bilgihan, A. (2016). Gen y customer loyalty in online shopping: An integrated model of trust, user experience and branding. Computers in Human Behavior, 61, 103-113. https://doi.org/10.1016/j.chb.2016.03.014

Biscaia, A. R., Rosa, M. J., Moura e Sá, P., \& Sarrico, C. S. (2017). Assessing customer satisfaction and loyalty in the retail sector. International Journal of Quality and Reliability Management. https://doi.org/10.1108/IJQRM-03-2015-0039

Budianto, A. (2019). Customer Loyalty: Quality of Service. Journal of Management Review, 3(1), 299-305. https://doi.org/10.25157/jmr.v3i1.1808

Cahya, I. (2020). Belanja Online Kala Pandemi Didominasi Milenial dan Gen Z. Merdeka.Com. https://www.merdeka.com/teknologi/belanjaonline-kala-pandemi-didominasi-milenial-dangen-z.html

Chaffin, T. (2018). Library Instruction, Net Promoter Scores, and Nudging beyond Satisfaction. In
Britto, Marwin, \& K. Kinsley (Eds.), Strategies and Approaches to Demonstrate Your Value, Impact, and Return on Investment (pp. 342-352). University Libraries Publications. https://openscholarship.wustl.edu/cgi/viewconten t.cgi? article $=1025 \&$ context $=$ lib_papers

Chen, S. C. (2012). The customer satisfaction-loyalty relation in an interactive e-service setting: The mediators. Journal of Retailing and Consumer Services, 19(2), 202-210. https://doi.org/10.1016/j.jretconser.2012.01.001

Chen, S. C. (2015). Customer value and customer loyalty: Is competition a missing link? Journal of Retailing and Consumer Services, 22(.), 107-116. https://doi.org/10.1016/j.jretconser.2014.10.007

Delgado-Ballester, E., \& Luis Munuera-Alemán, J. (2001). Brand trust in the context of consumer loyalty. European Journal of Marketing, 35(11/12), 1238-1258. https://doi.org/10.1108/eum0000000006475

Demenko, O. G., \& Savina, N. P. (2019). Program for the development of the digital economy: Challenges and prospects. Espacios, 40(25), 1-25. https://www.revistaespacios.com/a19v40n25/a19 v40n25p25.pdf

Dick, A. S., \& Basu, K. (1994). Customer loyalty: Toward an integrated conceptual framework. Journal of the Academy of Marketing Science, 22(2), 99-113. https://doi.org/10.1177/0092070394222001

Dimock, M. (2019). Where Millennials end and Generation Z begins | Pew Research Center. Pew Research Center. http://tonysilva.com/eslefl/miscstudent/downloadpagearticle s/defgenerations-pew.pdf

East, R., Gendall, P., Hammond, K., \& Lomax, W. (2005). Consumer Loyalty: Singular, Additive or Interactive? Australasian Marketing Journal, 13(2), 10-26. https://doi.org/10.1016/S14413582(05)70074-4

Eger, L., \& Mičík, M. (2017). Customer-oriented communication in retail and Net Promoter Score. Journal of Retailing and Consumer Services, 35(2017), $142-149$. https://doi.org/10.1016/j.jretconser.2016.12.009

Eroglu, E. (2014). The Changing Shopping Culture: Internet Consumer Behavior. Review of Business Information Systems (RBIS), 18(1), 35-40. https://doi.org/10.19030/rbis.v18i1.8541

Hamilton, D. F., Lane, J. V., Gaston, P., Patton, J. T., MacDonald, D. J., Simpson, A. H. R. W., \& Howie, C. R. (2014). Assessing treatment outcomes using a single question: The Net Promoter Score. Bone and Joint Journal, 96-B(5), 622-628. https://doi.org/10.1302/0301- 
Jurnal Bisnis dan Manajemen, Volume 22, No. 2, September 2021, p. 162-175

620X.96B5.32434

Hermawan, H. (2015). Analisis Pengaruh Bauran Pemasaran Terhadap Keputusan, Kepuasan Dan Loyalitas Konsumen Dalam Pembelian Roti Ceria Di Jember. Jurnal Manajemen Dan Bisnis Indonesia, $\quad 9(1), \quad$ 143-161. https://jurnal.unej.ac.id/index.php/BISMA/article /view/5904

IGI Global. (n.d.). What is Digital Platform. In Publishe of Timely Knowledge. https://www.igiglobal.com/dictionary/beusin/55829

Iprice. (2020a). Peta E-Commerce Indonesia. In iprice.co.id.

https://iprice.co.id/insights/mapofecommerce/

Iprice. (2020b). Southeast Asian Map of E-commerce, This Report Covers 6 Countries in Southeast Asia. In Iprice.co.id. https://iprisce.co.id/insights/mapofecommerce/en / when publish

Kiseleva, E. M., Nekrasova, M. L., Mayorova, M. A., Rudenko, M. N., \& Kankhva, V. S. (2016). The theory and practice of customer loyalty management and customer focus in the enterprise activity. International Review of Management and Marketing, 6(6S), 95-103. https://www.econjournals.com/index.php/irmm/a rticle/view/2930

Krol, M. W., de Boer, D., Delnoij, D. M., \& Rademakers, J. J. D. J. M. (2015). The Net Promoter Score - an asset to patient experience surveys? Health Expectations, 18(6), 3099-3109. https://doi.org/10.1111/hex.12297

KumparanTech. (2018, February 19). Generasi Millenial Dominasi Pengguna Internet di Indonesia. Techno \& Sains. https://kumparan.com/kumparantech/generasimillenial-dominasi-pengguna-internet-diindonesia/full

Lafley, A. G., Martin, R. L., Lafley, A. G., McGrath, R. G., Knudstorp, J. V., \& Champion, D. (2017). Customer loyalty is overrated. Harvard Business Review, 291(17), 1-32. https://www.oresky.eu/wpcontent/uploads/2017/09/Customer-Loyalty-IsOverrated.pdf

Lee, S. (2018). Net promoter score: Using NPS to measure IT customer support satisfaction. Proceedings ACM SIGUCCS User Services Conference, 63-64. https://doi.org/10.1145/3235715.3235752

Leninkumar, V. (2017). The Relationship between Customer Satisfaction and Customer Trust on Customer Loyalty. International Journal of Academic Research in Business and Social Sciences, $\quad 7(4), \quad 450-465$. https://doi.org/10.6007/ijarbss/v7-i4/2821

Lewis, B. R., \& Soureli, M. (2006). The antecedents of consumer loyalty in retail banking. Journal of Consumer Behaviour, 5(1), 15-31. https://doi.org/10.1002/cb.46

Malinverno, P., \& Moyer, K. R. (2017). From APIs to Ecosystems: API Economy Best Practices for Building a Digital Platform. In Gartner. https:/www.gartner.com/en/documents/3760363/ from-apis-to-ecosystems-api-economy-bestpractices-for-b

Mecredy, P., Wright, M. J., \& Feetham, P. (2018). Are promoters valuable customers? An application of the net promoter scale to predict future customer spend. Australasian Marketing Journal, 26(1), 39. https://doi.org/10.1016/j.ausmj.2017.12.001

Mowen, J. C., \& Minor, M. C. (2001). Consumer Behavior: A Framework. USA: Prentice Hall.

Novianty, D. (2019, May 16). Generasi Milenial Kuasai Penggunaan Internet Indonesia pada Tahun 2018. Suara.Com.

https://www.suara.com/tekno/2019/05/16/100858 /generasi-milenial-kuasai-penggunaan-internetindonesia-pada-tahun-

2018\#: :text=Ternyata\%2C generasi milenial menguasai pengguna,tahun sebanyak $82 \% 2 \mathrm{C} 7$ persen.

Oliver, R. L. (1999). Whence consumer loyalty? Journal of Marketing, 63(Special Issue), 33-44. https://doi.org/10.2307/1252099

Oxford University Press. (2019). Oxford Learner's Dictionaries. Oxford.

Pratminingsih, S. A., Lipuringtyas, C., \& Rimenta, T. (2013). Factors Influencing Customer Loyalty Toward Online Shopping. International Journal of Trade, Economics and Finance, 4(3), 104-110. https://doi.org/10.7763/ijtef.2013.v4.268

Pudjarti, S., Nurchayati, \& Putranti, H. R. D. (2019). Hubungan e-services quality dan e-loyalty dengan e-satisfaction pada konsumen Go-Jek dan Grab di Kota Semarang. Sosiohumaniora, 21(3), 237-246. http://jurnal.unpad.ac.id/sosiohumaniora/article/v iew/21491

Raassens, N., \& Haans, H. (2017). NPS and Online WOM: Investigating the Relationship Between Customers' Promoter Scores and eWOM Behavior. Journal of Service Research, $x x(\mathrm{x}), 1-$ 13. https://doi.org/10.1177/1094670517696965

Rafiq, M., Fulford, H., \& Lu, X. (2013). Building customer loyalty in online retailing: The role of relationship quality. Journal of Marketing Management, 29(3-4), 494-517. https://doi.org/10.1080/0267257X.2012.737356

Rahman, A. (2016). 'The Perspective of Net Promoter Score (NPS) in Grameenphone Ltd. [Business 
Jurnal Bisnis dan Manajemen, Volume 22, No. 2, September 2021, p. 162-175

School BRAC University]. http://dspace.bracu.ac.bd/xmlui/handle/10361/83 51

Reichheld, F. and R. M. (2011). The Ultimate Question 2.0. How net promoter companies Thrive in a customer-Driven World. Harvard Business Review Press. https://books.google.co.id/books?hl=en\&lr=\&id= YPY7n_OK0fsC\&oi=fnd\&pg=PR7\&dq $=\% 22 \mathrm{Th}$ e+Ultimate+Question+2.0+(How+Net+promoter +Companies+Thrive+in+a+CustomerDriven+World\%22\&ots=tgkb7B39Qs\&sig=GKr 09CSF_7gt59ICtldRORyLGKw\&redir_esc $=\mathrm{y} \# \mathrm{v}$ $=$ onepage $\& \mathrm{q}=\% 22 \mathrm{The}$ Ultimat

Rossanty, Y., Nasution, muhammad dharma tuah, \& Ario, F. (2018). Consumer Behaviour in Era Millennial. Lembaga penelitian dan penulisan ilmiah Aqli.

SAS. (2020). Transformasi Digital: Apa itu dan mengapa hal itu penting. SAS Institute Inc. https://www.sas.com/id_id/insights/datamanagement/digital-transformation.html

Setiawan, H., \& Sayuti, A. J. (2017). Effects of Service Quality, Customer Trust and Corporate Image on Customer Satisfaction and Loyalty: An Assessment of Travel Agencies Customer in South Sumatra Indonesia. IOSR Journal of Business and Management, 19(5), 31-40. https://doi.org/10.9790/487x-1905033140

Siagian, H., \& Cahyono, E. (2014). Analisi website quality, trust dan loyalty pelanggan online shop. Jurnal Manajemen Pemasaran, 8(2), 55-61. https://doi.org/10.9744/pemasaran.8.2.55-61

Simarmata, B. T. (2019). Mengukur tingkat kepuasan nasabah dengan Net Promoter Score pada PT. BPD Jawa Barat dan Banten, Tbk. Cabang Medan. Jurnal Ilmiah Skylandsea, 3(2), 257-264.

Sirclo, T. (2020). Jumlah Pengguna E-Commerce Indonesia di Tahun 2020 Meningkat Pesat. SirClo.Com. https://www.sirclo.com/jumlahpengguna-e-commerce-indonesia-di-tahun-2020meningkat-pesat/

Situmorang, S. H., Rini, E. S., \& Muda, I. (2017). Customer Experience, Net Emotional Value and Net Promoter Score on muslim middle class women in Medan. International Journal of Economic Research, 14(20), 269-283.

SivaKumar, A. K., \& Gunasekaran, A. (2017). An Empirical Study on the Factors Affecting Online Shopping Behavior of Millennial Consumers. Journal of Internet Commerce, .(.), 1-12. https://doi.org/10.1080/15332861.2017.1317150

SkalaNews. (2019). Pertumbuhan e-Commerce Indonesia Capai 78 Persen. Kementerian Informasi Dan Komunikasi. https://kominfo.go.id/content/detail/16770/kemko minfo-pertumbuhan-e-commerce-indonesiacapai-78-persen/0/sorotan_media

So, K. K. F., King, C., Sparks, B. A., \& Wang, Y. (2016). The Role of Customer Engagement in Building Consumer Loyalty to Tourism Brands. Journal of Travel Research, 55(1), 64-78. https://doi.org/10.1177/0047287514541008

Srivastava, M., \& Kaul, D. (2016). Exploring the link between customer experience-loyalty-consumer spend. Journal of Retailing and Consumer Services, 31(.), 277-286. https://doi.org/10.1016/j.jretconser.2016.04.009

Statista Research Department. (2020, September). Top 10 e-commerce sites in Indonesia as of 2 nd quarter 2020 , by monthly traffic. Statista Research Department.

https://www.statista.com/statistics/869700/indone sia-top-10-e-commerce-sites/

Wahyono, B. (n.d.). Perbedaan Antara Pelanggan Dan Konsumen. In Pendidikan Ekonomi. http://www.pendidikanekonomi.com/2012/08/per bedaan-antara-pelanggan-dan-konsumen.html

Wang, F., \& Zhang, X. P. (2015). The role of the Internet in changing industry competition. Information and Management, 52(1), 71-81. https://doi.org/10.1016/j.im.2014.10.006

Wang, S., Hu, Q., \& Liu, W. (2017). Price and qualitybased competition and channel structure with consumer loyalty. European Journal of Operational Research, 262(1), 563-574. https://doi.org/10.1016/j.ejor.2017.03.052

Wicaksono, B. D. (2019, January 19). IMR 2019: Begini Kebiasaan Millennial saat Belanja Online. IDN Time.Com. https://www.idntimes.com/tech/trend/bayu/survei -ims-2019-kebiasaan-millennial-saat-belanjaonline-ims $2019 / 5$

Widyanita, F. A. (2018). Analisi pengaruh kualitas pelayanan e-commerce terhadap kepuasan konsumen Shopee Indonesia pada mahasiswa Fakultas Ekonomi UII pengguna Shopee [Universitas Islam Indonesia]. In Universitas Islam Indonesia. https://dspace.uii.ac.id/bitstream/handle/1234567 89/7821/JURNAL Fika Ayu Widyanita.pdf?sequence $=2 \&$ isAllowed $=\mathrm{y}$

Wikipedia. (2020). Millennials. In Wikipedia. https://en.wikipedia.org/wiki/Millennials

Wohllebe, A., Ross, F., \& Podruzsik, S. (2020). Influence of the Net Promoter Score of Retailers on the Willingness of Consumers to Install Their Mobile App. International Journal of Interactive Mobile Technologies (IJIM), 14(19), 124-139. https://doi.org/10.3991/ijim.v14i19.17027 
Jurnal Bisnis dan Manajemen, Volume 22, No. 2, September 2021, p. 162-175

Wu, M.-Y., \& Tseng, L.-H. (2014). Customer Satisfaction and Loyalty in an Online Shop: An Experiential Marketing Perspective. International Journal of Business and Management, 10(1), 104114. https://doi.org/10.5539/ijbm.v10n1p104

Yu, Y. T., \& Dean, A. (2001). The contribution of emotional satisfaction to consumer loyalty. International Journal of Service Industry Management, 12(3), 234-250. https://doi.org/10.1108/09564230110393239

Zeithaml, V. A., Berry, L. L., \& Parasuraman, A. (1996). The behavioral consequences of service quality. Journal of Marketing, 60(2), 31-46. https://doi.org/10.2307/1251929. 